\title{
Correction: Suppression of interferon gene expression overcomes resistance to MEK inhibition in KRAS-mutant colorectal cancer
}

\author{
Steve Wagner ${ }^{1} \cdot$ Georgios Vlachogiannis $^{2}$ - Alexis De Haven Brandon ${ }^{1} \cdot$ Melanie Valenti $^{1} \cdot$ Gary Box $^{1}$. \\ Liam Jenkins ${ }^{3}$ - Caterina Mancusi ${ }^{1}$ - Annette Self ${ }^{1} \cdot$ Floriana Manodoro $^{4} \cdot$ loannis Assiotis ${ }^{4}$ Penny Robinson ${ }^{4}$. \\ Ritika Chauhan ${ }^{4} \cdot$ Alistair G. Rust ${ }^{4} \cdot$ Nik Matthews $^{4} \cdot$ Kate Eason $\mathbb{D}^{2} \cdot$ Khurum Khan $^{5} \cdot$ Naureen Starling $^{5}$. \\ David Cunningham ${ }^{5}$ - Anguraj Sadanandam ${ }^{2} \cdot$ Clare M. Isacke $^{3} \cdot$ Vladimir Kirkin $^{1} \cdot$ Nicola Valeri $^{2,5}$. \\ Steven R. Whittaker $\mathbb{D}^{1}$
}

Published online: 30 May 2019

(c) The Author(s), under exclusive licence to Springer Nature Limited 2019. This article is published with open access

\section{Correction to: Oncogene}

https://doi.org/10.1038/s41388-018-0554-z, published online 23 October 2018

Following publication of this article it was noted that Supplementary Tables $1-5$ were omitted.

These have now been added to the HTML version of the Article.
Open Access This article is licensed under a Creative Commons Attribution 4.0 International License, which permits use, sharing, adaptation, distribution and reproduction in any medium or format, as long as you give appropriate credit to the original author(s) and the source, provide a link to the Creative Commons license, and indicate if changes were made. The images or other third party material in this article are included in the article's Creative Commons license, unless indicated otherwise in a credit line to the material. If material is not included in the article's Creative Commons license and your intended use is not permitted by statutory regulation or exceeds the permitted use, you will need to obtain permission directly from the copyright holder. To view a copy of this license, visit http://creativecommons. org/licenses/by/4.0/.
Steven R. Whittaker

steven.whittaker@icr.ac.uk

1 Division of Cancer Therapeutics, The Institute of Cancer Research, London, UK

2 Division of Molecular Pathology, The Institute of Cancer Research, London, UK

3 Breast Cancer Now Research Centre, The Institute of Cancer Research, London, UK

4 Tumour Profiling Unit, The Institute of Cancer Research, London, UK

5 Department of Medicine, Royal Marsden NHS Foundation Trust, London, UK 